\title{
DRUG UTILIZATION TRENDS IN ENT OUT PATIENT DEPARTMENT IN A PRIVATE TEACHING HOSPITAL IN BANGLADESH
}

\author{
OMMA HAFSA ANY ${ }^{1}$, LAYLA AFROZA BANU ${ }^{2}$, REZINA SULTANA ${ }^{3}$, NASHID TABASSUM KHAN $^{4}$, MARUFA HOSSAIN ${ }^{5}$, \\ SELINA AKHTAR ${ }^{6}$
}

${ }^{1}$ Assistant Professor, Department of Pharmacology \& Therapeutics, Z.H. Sikder Women's Medical College, Dhaka

${ }^{2}$ Professor \& Head, Department of Pharmacology \& Therapeutics, Shaheed Suhrawardy Medical College, Dhaka

${ }^{3}$ Assistant Professor, Department of Pharmacology \& Therapeutics, Z.H. Sikder Women's Medical College, Dhaka

${ }^{4}$ Assistant Professor, Department of Forensic Medicine, Z.H. Sikder Women's Medical College, Dhaka

${ }^{5}$ Assistant Professor, Department of Microbiology, Z.H. Sikder Women's Medical College, Dhaka

${ }^{6}$ Assistant Professor, Department of Physiology, Z.H. Sikder Women's Medical College, Dhaka

\begin{abstract}
A cross-sectional descriptive study was carried out among individuals attending the ENT out-patient department from $1^{\text {st }}$ June 2012 to 30th August 2012 in Z.H. Sikder Women's Medical College\& Hospital, Dhaka. Bangladesh. The primary aim of this study was to generate up to date information on drug use in the ENT outpatient service of our hospital indications for use. A total of 150 prescriptions were randomly audited at varying time interval from the department of ENT during a three month period. The data was collected in customized proforma. Maximum cases were of otitis media 74(49.33\%), sinusitis 24 (16.00\%), tonsilitis $15(10.00 \%)$, pharyngitis $14(09.33 \%)$, DNS $14(09.33 \%)$, rhinitis $07(04.66 \%)$, adenoiditis 02 (01.33\%). The average number of drugs used in the prescriptions was $2.94 \%$. None of the drugs were prescribed by generic name. All of them were prescribed with trade names. The topical preparations were the most commonly prescribed drugs. Middle and lower income group of patients generally attend outpatient department, the average cost per prescription was 112 taka. The average cost to be high in this group. Educational sessions for the doctors at different levels to encourage prescribing by generic names and on correct writing of prescriptions may be considered. Studies covering a larger number of patients and for a longer time period are required. A greater number of patients can be studied, seasonal variations can be overcome and drug utilization can be measured quantitatively.
\end{abstract}

Keywords: Drug utilization studies, topical, antimicrobials, NSAIDs, Prescription audit.

(Bangladesh J Physiol Pharmacol 2014;30(2): 41-45)

\section{INTRODUCTION}

Medicine utilization research has been defined by the World Health Organization (WHO) as "the marketing, distribution, prescription and use of drugs in a society, with special emphasis on the resulting medical, social and economic consequence". ${ }^{1}$ The assessment of drug utilization is important for clinical, educational and economic purposes. ${ }^{2}$ Study of medicine utilization trends are powerful, exploratory tools to ascertain role of drugs in medical practice create a sound and economic basis for health care. Studies on the process of medicine utilization focus on the factors related to the prescribing, dispensing, administering, and taking of medication, and its associated events, covering the medical and non- medical determinants of medicine utilization, their effects as well as studies of how this

Address for correspondence: Dr. Omma Hafsa Any, Assistant Professor of Pharmacology, Z.H. Sikder Women's Medical College, Dhaka. E-mail: omma.hafsa.anee@gmail.com Mobile: 01676714083 relates to the effects of medicine use. ${ }^{3,4}$ The characterization of medicine utilization may be extended linking prescription data to the reasons of specific prescribing. They include the concept of appropriateness ${ }^{5}$ that must be assessed relative to indication for treatment. Prescribing patterns need to be evaluated periodically to increase the therapeutic efficacy, decrease adverse effects and provide feedback to prescriber. ${ }^{6,7}$ Medicine utilization studies and reviews are useful for obtaining information about pattern of medicine use and to identify expensive medicines. ${ }^{8-12}$ Prescribing at outpatients is done by various types of health professionals and outpatient clinics deliver therapeutic service to large quarter of patients. Different types of irrationalities were observed both at outpatient of primary care facilities, ${ }^{13}$ cost-effectiveness of specific type of care $^{14}$ as well as adherence to protocol $^{15}$. Assessment of prescribing pattern in important medical care facilities is of obvious relevance 
to identify problems regarding rational use and to propose interventions.

The objective of the present study was to evaluate and compare patterns of prescribing practice. The primary aim of this study was to generate up to date information on medicine use in the ENT outpatient department of our hospital and indications for use, appropriateness of its use. This would encourage good evidence based practice and facilitate appropriateness of medicines.

\section{MATERIALS AND METHODS}

A cross sectional descriptive study was carried out over a three months period from at a teaching hospital, a tertiary care hospital. The patient and their prescription were used as source of data. A total 150 patients were included in this study. Follow up visits during the study period were included and were counted as separate visits. Patients visiting the emergency department or who got admitted during OPD visit were not included in the study. The data was collected in customized Proforma in the form of an audit questionnaire. It contained patient particulars, diagnosis, investigations, drug details and information from the prescriber regarding the indication for prescribing agents (both topical and oral), underlying infection, duration of therapy and details of any concomitant medications. Cost of the individual prescriptions worked from prices as given in hospital pharmacy. The data was expressed as percentage and total numbers.

\section{RESULT}

\section{DEMOGRAPHY}

The ENT OPD patients constituted 150 of the total patients attending the hospital OPD between the period of $1^{\text {st }}$ June 2012 to $30^{\text {th }}$ August 2012. The analysis of demographic data showed that of 150 patients 67 were female and 83 were male.

\section{PREVALENCE}

The incidence of ear affections were the maximum $74(49.33 \%)$, followed by throat $24(16.00 \%)$ and least were others infection. The various diagnosis for the ear diagnosis were otitis media (acute and chronic), wax. The throat affection (tonsillitis, pharyngitis, mouth ulcers). The distribution of nose affections were infective rhinitis, allergic rhinitis, sinusitis.

\section{AVERAGE NUMBER OF DRUGS PRESCRIBED}

The average number of medicines used in the prescriptions was $2.94 \%$. About 23 prescriptions containing 04 medicines, 94 prescriptions had 03 and 33 prescriptions had 02 medicines. None of the medicines were prescribed by generic name. All of them were prescribed with trade names. The common categories of medicines prescribed to ENT outpatients are as shown in the Table No. I

Table-I

Medicines prescribed

\begin{tabular}{|l|l|}
\hline Medicines & Percentage \\
\hline Antiallergics & $134(30.30 \%)$ \\
\hline Antibiotics & $109(24.66 \%)$ \\
\hline Topical preparation & $94(21.26 \%)$ \\
\hline NSAIDS & $54(12.12 \%)$ \\
\hline Multivitamins & $30(6.78 \%)$ \\
\hline Antiulcers & $21(4.75 \%)$ \\
\hline
\end{tabular}

\section{ANTIALLERGICS}

The antiallergics used were as Cetrizine, Fexofenadine, Loratidine, Chlorpheniramine, Pheniramine.

\section{ANTIBIOTICS}

The antibiotics commonly prescribed were Macrolides 79, Amoxicillin 24, Fluroquinolones 20 and Cephalosporin 13. The Macrolides commonly prescribed were Azithromycin, erythromycin and Roxithromycin. Sparfloxacin was the common Fluroquinolone used. Ciprofloxacin was used in 4 cases. Amoxicillin was used alone, and in combination with Clavulanic acid. The most commonly used cephalosporins was cefuroxime.

Table-II

Antibiotics prescribed

\begin{tabular}{|c|c|}
\hline Name of the Medicine & Percentage \\
\hline $\begin{array}{l}\text { 1. Macrolids } \\
\text {-Azithromycin } \\
\text {-Erythromycin } \\
\text {-Roxithromycin }\end{array}$ & $\begin{array}{l}79(58.08 \%) \\
54(64.35 \%) \\
13(16.45 \%) \\
12(15.18 \%)\end{array}$ \\
\hline $\begin{array}{l}\text { 2. Penicillins } \\
\text {-Amoxicillin + Clavulanic acid } \\
\text {-Amoxicillin }\end{array}$ & $\begin{array}{l}24(17.64 \%) \\
18(75 \%) \\
06(25 \%)\end{array}$ \\
\hline $\begin{array}{l}\text { 3. Fluoroquinolones } \\
\text {-Sparfloxacin } \\
\text {-Ciprofloxacin }\end{array}$ & $\begin{array}{l}20(14.70 \%) \\
16(80 \%) \\
04(20 \%)\end{array}$ \\
\hline $\begin{array}{l}\text { 4. Cephalosporins } \\
\text {-Cefuroxime } \\
\text {-Cefaclor }\end{array}$ & $\begin{array}{l}13(09.55 \%) \\
11(84.61 \%) \\
02(15.38 \%)\end{array}$ \\
\hline
\end{tabular}

\section{TOPICAL PREPARATIONS}

The topical preparation used were gentamicin, ciprofloxacin, clotrimazole, steroid combination drops (dexamethasone, betamethasone in combination with neomycin, clotrimazole). The ear softeners also used. Antiseptic mouth washes were also prescribed. 


\section{ANALGESICS}

The analgesics used were Ibuprofen + Paracetamol, Diclofenac, Paracetamol.

\section{DURATION OF THE PRESCRIPTION}

The minimum duration of the prescription was 5 days. The duration for 18 prescription was for 15 days. 32 prescriptions were prescribed for 10 days. 91 were given for 7 days and another 9 for 5 days.

\section{cosT}

The total amount spent on these prescriptions was 16,800 taka. The average cost per prescription was 112 taka.

\section{DISCUSSION}

A prescription by a doctor may be taken as an indication of the doctors' attitude towards the disease and the role of medicines in its treatment. With regard to the average number of medicines per prescription, the value found in the present study was 2.94. In similar studies conducted, the lower values found were 1.65 in Zimbabwe, ${ }^{16}$ Jordan 2.3, ${ }^{17}$ Brazil $2.4{ }^{18}$ India $2.7^{19}$ and Nepal $2.91 .^{20}$ The average (mean) number of medicines per prescription is an important parameter while doing a prescription audit. A hospital based study in India had reported a mean number of two medicines. ${ }^{21}$ The mean number of medicines prescribed in this study was more than other studies reported in the literature. ${ }^{22-23}$ It is preferable to keep the mean number of medicines per prescription as low as possible since higher figures always lead to increased risk of interactions, development of bacterial resistance and increased cost. ${ }^{24-25}$ The number is however, higher than that reported in previous studies. ${ }^{9,10,26}$ Maximum cases were of otitis media 74 (49.33\%), sinusitis $24(16.00 \%)$, tosilitis $15(10.00 \%)$, pharyngitis $14(09.33 \%)$, DNS 14 $(09.33 \%)$, rhinitis $07(04.66 \%)$, adenoiditis 02 (01.33\%). ${ }^{24,25}$ In another study, most patients reported with URTI (32.56\%), CSOM (18.3\%), sinusitis (6.28\%), tonsillitis $(5.75 \%)$, furuncle $(4.71 \%)$. Pharyngitis $(3.66 \%)$, abscess (3.14\%), ASOM (2.61\%) and miscellaneous (19.37\%). ${ }^{27}$ In another study in India, maximum cases were of otitis media $21(20.51 \%)$, wax $19(18.62 \%)$, tonsillitis $16(15.68 \%)$, infective rhinitis 5 $(14.7 \%){ }^{28}$ The common categories of medicines prescribed to ENT outpatients were antiallergics 134 (30.30\%), antimicrobials 109 (24.66\%), topical preparation $94(21.26 \%)$, NSAIDS $54(12.12 \%)$. This study shows a high use of antallergics, which seems justified in the ENT OPD. The antiallergics used were as Cetrizine, Fexofenadine, Loratidine, Chlorpheniramine and Pheniramine, of which Loratidine were maximum prescribed medicine from the second generation non sedating antihistamines. In this study, it was observed that the average prescribing frequency of antimicrobials per prescription was mostly Macrolides 79 (58.08\%),
Azithromycin, 54 (64.35\%), Erythromycin 13 (16.45\%), Roxithromycin $12(15.18 \%)$. It was further observed that antimicrobials were prescribed to patient with infective etiology, which is low. Mostly, the antimicrobials were prescribed for diseases like otitis media, tonsillitis, pharyngitis, infective rhinitis, allergic rhinitis and sinusitis. The use is in these conditions seems justifiable as most of these conditions are viral or bacterial in origin. Schwartz et al pointed out that despite the concern over injudicious use of AMAs in acute purulent rhinitis; it was observed $77 \%$ of the prescribers continue to prescribe AMAs in this condition. ${ }^{28}$ The antibiotics commonly prescribed were Macrolides, Amoxicillin, Fluroquinolones and Cephalosporin. The Macrolides commonly prescribed were Azithromycin, erythromycin and Roxithromycin. Sparfloxacin was the common Fluroquinolone used. Ciprofloxacin was used in 4 cases in the subjects though low but is generally not indicated in treatment of ENT infections. Amoxicillin was used alone, and in combination with Clavulanic acid which though is low but is not a rational FDC as per WHO guidelines. The prescribed cephalosporins were cefuroxime and cefaclor in two subjects. However, our study was confined to the ENT OPD while the Pakistani and the Indian studies were carried out in different OPDs. ${ }^{29-30}$ It will be difficult to compare our data with that obtained from the studies. The commonly used FDC were NSAIDS+ Decongestants 41 (53.24\%), Diclofenac + Paracetamol $16(20.77 \%)$, and Ibuprofen + Paracetamol $12(15.58$ $\%)$. These figures seem quite appropriate for an ENT OPD. However, due to different patient populations the values are not comparable. The percentage of drugs prescribed by generic name was $0 \%$ in the study which is very much less than that reported in studies conducted in Combodia (99.8\%), ${ }^{31}$ India(73.4\% $)^{32}$ and Nepal $(21.3 \%)^{33}$. The most common reasons for not prescribing generic name in Bangladesh may be tradition, marketing of medicine in trade names and divertive drug promotion techniques of the pharmaceutical companies. In this study, pain is the commonly experienced symptom among the patients. NSAIDS used along with antiulcerent drugs. The average cost per prescription was 112 taka for 10 days duration. Our study had a number of limitations. The study was carried out over a three month period and seasonal variations in disease and prescribing patterns may not have been taken into account. One hundred and fifty patients/prescriptions were randomly selected for analysis and these may not have been representative of the patient population attending the ENT OPD during the study period. The number of medicines prescribed in the prescriptions is low. The patients' knowledge of the correct dose, proper time to take the medicine, whether the medicine is to be taken before or after food and the proper method of applying topical preparations were not ascertained. The prescribers were aware of the study and this may have influenced prescribing habits. Percentage of encounters 
with an antibiotic and an injection prescribed was low. This is a welcome sign and has to be encouraged. Educational interventions to improve prescribing were tried and found effective to improve prescribing at different levels and categories of prescribers. ${ }^{12-14}$ Such studies are necessary to obtain baseline data on drug use and create a database for comparison with future studies Implementation of educational programs to change the attitude of prescribers for improving medicine utilization is the demand of present scenario. Standard Therapeutic Guidelines can be formulated for the common ENT infections and followed universally, which would promote rational use of medicines especially antimicrobials. ${ }^{33}$ Nevertheless, regular prescription audit monitoring with reviewing of prescribing pattern in indoor and outdoor patients at varying time interval in a particular location, would give the feedback on the rational use of medicines.

\section{CONCLUSION}

The mean number of drugs was low. There was no generics prescribed and efforts to encourage prescribing by generic name should be initiated. The average cost seems to be high. Percentage of encounters with antibiotic prescribed is satisfactory for the condition. This is a welcome sign and has to be encouraged.

\section{ACKNOWLEDGEMENTS}

The authors acknowledge the Vice-Principal of Z.H. Sikder Women's Medical College \& Hospital for administrative support and cooperation during survey.

\section{REFERENCES}

1. WHO. Action programme for Essential drugs. How to investigate drug use in health facilities. WHO, 1993.

2. Uppal $R$, Nayak $P$, Sharma $P L$. Prescribing trends in internal medicine. Int J Clin Pharm Ther Toxicol 1984; 22: 363-370.

3. Lunde PK, Baksaas I. Epidemiology of drug utilization basic concepts and methodology. Acta Med Scand Suppl 1988; 721: 711.

4. Strom BL. Pharmacoepidemiology. Fourth ed: John Wiley \& Sons, Ltd 2005.

5. Strom BL, Melmon KL, Miettinen OS. Post-marketing studies of drug efficacy. Arch Intern Med 1985; 145: 17914.

6. Krishnaswamy K, Dinesh Kumar B, Radhaiah GA. Drug use surveyprecepts and practice. Eur J Clin Pharmacol 1985; 29: 363-370.

7. Pradhan SC, Shedwade DG, Shashindran CH, Bapna JS. Drug utilization studies. National Med J India 1988; 1: 185-189.

8. Marshner JP, Thurmann P, Harder S, Rietbroc N. Drug utilization review on a surgical intensive care unit. Int J Clin Pharmacol The 1994; 32: 447-451.

9. Rashid HU, Choudhury SAR, Islam N. Pattern of antibiotic use in two teaching hospitals. Trop Doctor 1986; 16: 152.

10. Guyon AB, Barman, Ahmed JU, Ahmed AU, Alam MS. A baseline survey on use of drugs at the primary health care level in Bangladesh. Bull of WHO 1994; 72: 265-71.

11. Afsan M, Haque MME, Alam MM, Noor N. Audit of Prescribing Practices to Evaluate Rational Use of Medicines in the OPD of
Orthopaedics in a Private Medical College Hospital. J Shaheed Suhrawardy Med Coll. 2012; 4: 39-42.

12. Chowdhury AK, Rahman MS, Faroque AB, Hasan GA, Raihan SZ Excessive Use of Avoidable Therapeutic Injections in the Upazilla Health Complexes of Bangladesh. Mym Med J 2008; 17(2 Suppl): S59-64.

13. Islam MS, Rahman MS, Misbahuddin M. Impact of 'Prescription Audit \& Feedback' on Pattern of Prophylactic Antimicrobials in Caesarean Section: a Cost Reduction Perspective. Bangladesh J Physiol Pharmacol 2007; 23: 1-9.

14. Das AK, Rahman MS. Prescribing Vitamins at Primary Health Care Level: Exploration of Facts, Factors and Solution. Bangladesh J Pharmacol 2010; 5: 92-7.

15. Afreen S, Rahman MS. Adherence to treatment guidelines in a university hospital: Exploration of facts and factors. Bangladesh J Pharmacol 2014; 9: 182-88.

16. Lessing C, Trap B. Zimbabwe Essential Drugs Action Programme (ZEDAP) 1995. Ministry of Health and Child Welfare Directorate of Pharmacy.

17. Otoom S, Batieha A, Hadidi H, Hasan M, Al-Saudi K. Evaluation of drug use in Jordan using $\mathrm{WHO}$ prescribing indicators. East Mediterr Health J 2002; 8: 537-543.

18. Acurcio FA, Perini E, Magalhases SM, Terceiro LG, Vieira Filho JM, Countinho $\mathrm{KE}$, et al. Analysis of medical prescriptions dispensed at health centers in Belo Horizonte, Minas Gerais, Brazil. Cad Saude Publica 2004; 20: 72-79.

19. Mhetre NA, Bodhankar SL, Pandit VA, Zambare GN. Study of pattern of drug usage in an urban area. Indian Pharmacol 2003; 35: 316-317.

20. Alam K, Mishra P, Prabhu M, Shankar PR, Palaian S, Bhandari RB, et al. A study on rational drug prescribing and dispensing in outpatients in a tertiary care teaching hospital of Western Nepal. Kathmandu Univ Med J 2006; 4: 436-443.

21. Hede SS, Diniz RS, Agshikar NV, Dhume VG. Pattern of prescribed and OTC drugs in North Goa. Indian J Pharmacol 1987; 19: 145148.

22. Srishyla MV, Krishnamurthy M, Naga Rani MA, Clare M, Andrade C, Venkataraman BV. Prescription audit in an Indian hospital setting using the DDD (defined daily dose) concept. Indian J Pharmacol 1994; 26: 23-28.

23. Rishi RK, Sangeeta S, Surendra K, Tailang M. Prescription audit: experience in Garhwal (Uttaranchal), India. Trop Doct 2003; 33: 76-79.

24. Atanasova I, Terziivanov D. Investigations on antibiotics in a hospital for a one year period. Int J Clin Pharm Ther 1995; 33: 3233.

25. Till B, Williams L, Oliver SP, Pollans PI. A survey of inpatient antibiotic use in a Teaching Hospital. S Afr Med J 1991; 8: 7-10.

26. Sarkar C, Das B. Prescribing trends in a teaching hospital in western Nepal. JNGMC 2002; 2: 4-7.

27. Pramila Y, Vanita K, Preety L, Siddharth J. Drug utilization trends in ENT outpatient Department in a tertiary Hospital. Vol1.ISSN0975-6299.

28. Schwartz RH, Freij BJ, Ziai M, Sheridan MJ. Antimicrobial prescribing for acute purulent rhinitis in children: a survey of pediatricians and family practitioners. Pediatr Infect Dis J 1997; 16: $185-190$.

29. Das BP, Adhikari N, Garg M, Rauniar GP, Naga Rani MA. Utilization pattern of nonsteroidal anti-inflammatory drugs (NSAIDs) in orthopaedic practice at a tertiary care hospital in eastern Nepal. J Nep Med Assoc 2000; 39: 315- 318. 
30. Biswas NR, Biswas RS, Pal PS, Jain SK, Malhotra SP, Gupta A, Pal $\mathrm{SN}$. Patterns of prescriptions and drug use in two tertiary hospitals in Delhi. Indian J Physiol Pharmacol 2000; 44: 109-112.

31. Chareonkul C, Khun VL, Boonshuyar C. Rational drug use in Combodia: study of three pilot health centers in Kampong Thom Province. Southeast Asian J Trop Med Public Health 2002; 418424.

32. Karande $S$, Sankhe $P$, Kulkarni $M$. Patterns of prescription and drug dispensing. Indian J Pediatr 2005; 72: 117-121.

33. Shankar PR, Pranab KS, Upadhyay DK, Dubey AK, Subish P. Drug Utilization among surgical outpatients. TMJ 2006; 56: 230-234. 